\title{
Reaction Behaviors of Various Agglomerates in Reducing the Temperature of the Thermal Reserve Zone of the Blast Furnace
}

\author{
Kenichi HIGUCHI, ${ }^{1) *}$ Kazuya KUNITOMO ${ }^{21}$ and Seiji NOMURA ${ }^{1)}$ \\ 1) Process Research Laboratories, Nippon Steel Corporation, 20-1 Shintomi, Futtsu, Chiba, 293-8511 Japan. \\ 2) Department of Materials Science and Engineering, Faculty of Engineering, Kyushu University, 744 Motooka, Nishi-ku, \\ Fukuoka, 819-0395 Japan.
}

(Received on March 3, 2020; accepted on June 10, 2020)

\begin{abstract}
As an innovative measure to mitigating $\mathrm{CO}_{2}$ emissions during ironmaking, the enhancement of carbon reactivity in blast furnaces is promising. It can reduce the temperature of the thermal reserve zone (TRZ), which is among the limiting factors to reaction efficiency in blast furnaces, thereby enabling operation under a low reducing agent rate (RAR). Therefore, reaction behaviors of two types of agglomerates with high carbon reactivity, composite agglomerates (CAs), and Ferro-coke, were evaluated using a softeningmelting tester and via large-scale thermogravimetry. Process estimation of the blast furnace using them was also performed using a counter-current reaction simulator. CAs exhibited low-temperature gasification, efficiently promoting reduction by mixing with sintered ores. The carbon-consumption ratios of CAs and Ferro-coke were higher than that of coke. The reactive coke agglomerate, which is reinforced CAs with high carbon content toward reducing the RAR, exhibited the highest carbon reactivity, because of the coupling phenomena between the gas reduction of iron oxide and gasification of carbon. The addition of metallic iron to the CA increased the consumption of carbon and reduction of sintered ores, because of the catalytic effect. A combined use of the CA and Ferro-coke in the blast furnace successfully reduced the temperature of the TRZ by $150^{\circ} \mathrm{C}$, offering the potential to decrease RAR by $35 \mathrm{~kg} / \mathrm{t}-\mathrm{HM}$. Estimation of the distance between carbon and iron oxide or metallic iron in these agglomerates revealed that reducing the temperature of the TRZ by them was closely associated with shortening the distance.
\end{abstract}

KEY WORDS: ironmaking; blast furnace; agglomeration; composite; Ferro-coke; carbon reactivity; gasification; reduction; reducing agent rate (RAR); catalyst.

\section{Introduction}

$\mathrm{CO}_{2}$ must be reduced for mitigating global warming. The product emissions from Japan account for $3.5 \%$ of the global $\mathrm{CO}_{2}$ emissions, $14 \%$ of which are from the steel industry. ${ }^{1)}$ Half of these are generated by ironmaking, as it uses coal as a resource. Using high-reactivity raw materials is one of the promising measures for decreasing the reducing agent rate (RAR) of blast furnaces to reduce $\mathrm{CO}_{2}$ emissions in ironmaking. In this decade, many types of high-reactivity raw materials have been proposed to control the reduction equilibrium state (the W point in RIST diagram), which is one of the limiting factors for reaction efficiency in blast furnaces.

One of the measures controlling the reduction equilibrium of blast furnaces is reducing the temperature of the thermal reserve zone (TRZ) by increasing the carbon reactivity. Both the enhancement of chemical reactivity and reduction in the

\footnotetext{
* Corresponding author: E-mail: higuchi.t9g.kenichi@jp.nipponsteel.com
}

size of carbonaceous materials are methods to increase the carbon reactivity. Accordingly, two types of agglomerates were investigated in this study, as depicted in Fig. 1.

The first type is the agglomerate comprising fine carbonaceous materials and fine iron oxides, hereafter referred to as the composite agglomerate (CA). It has high carbon reactivity and high reducibility because of the coupling phenomena between the gas reduction of iron oxides (Eq. (1)) and gasification of carbon (Eq. (2)). ${ }^{2)}$

$$
\begin{gathered}
\mathrm{FeO}+\mathrm{CO}=\mathrm{Fe}+\mathrm{CO}_{2} \\
\mathrm{C}+\mathrm{CO}_{2}=2 \mathrm{CO}
\end{gathered}
$$

Although the high reactivity of CA was known, ${ }^{3)}$ we previously observed an excellent potential of reinforced CAs with high carbon content toward reducing the RAR, ${ }^{4)}$ and accordingly, we commercialized the aforementioned CAs as reactive coke agglomerate (RCA). ${ }^{5}$

The second type of agglomerate is Ferro-coke, which has a structure with homogeneously distributed fine metallic 
iron in a coke matrix. It also has high carbon reactivity ${ }^{6,7)}$ because of the redox cycle between the direct reduction of iron oxide (Eq. (3)) and oxidation of iron (Eq. (4)). ${ }^{8)}$

$$
\begin{aligned}
\mathrm{FeO}+\mathrm{C} & =\mathrm{Fe}+\mathrm{CO} \\
\mathrm{Fe}+\mathrm{CO}_{2} & =\mathrm{FeO}+\mathrm{CO}
\end{aligned}
$$

In addition to the advantage of having the high carbon reactivity similar to that of $\mathrm{CA}$, Ferro-coke might further decrease RAR because of M.Fe charging to blast furnace. The reduction of the RAR was successfully confirmed in the plant tests using the Ferro-coke-based agglomerate called carbon iron composite (CIC). ${ }^{9}{ }^{9}$

However, investigations on the reaction behavior, particularly on the carbon reactivity of these agglomerates, are lacking. The information comparing their reaction behaviors is still limited.

Therefore, in this study, we investigated the reaction behaviors of CA and Ferro-coke, as well as their potential toward decreasing RAR through reducing the temperature of TRZ, by using a softening-melting tester and performing large-scale thermogravimetric analysis. We also estimated the process of the blast furnace by charging these agglomerates using a counter-current reaction simulator.
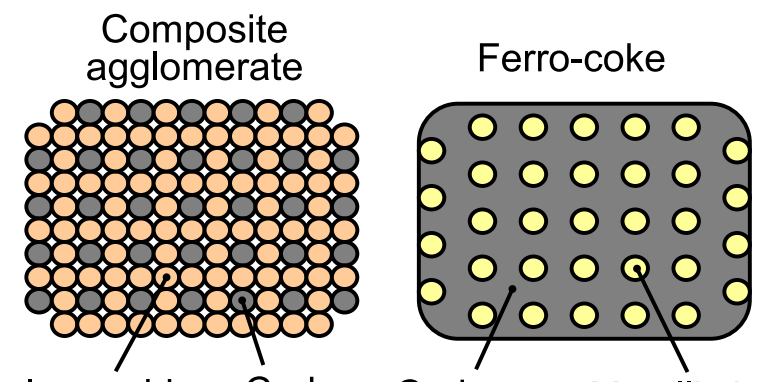

Iron oxide Carbon Carbon Metallic iron

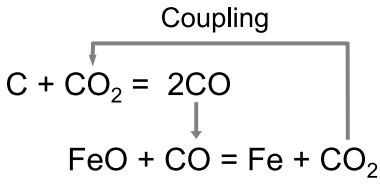

$$
\left.\begin{array}{c}
\text { Catalyst (Redox) } \\
\mathrm{C}+\mathrm{CO}_{2} \longrightarrow 2 \mathrm{CO} \\
\mathrm{FeO}+\mathrm{C}=\mathrm{Fe}+\mathrm{CO} \\
\mathrm{Fe}+\mathrm{CO}_{2}=\mathrm{FeO}+\mathrm{CO}
\end{array}\right)
$$

Fig. 1. Innovative agglomerates for breaking through the operational limit due to the reduction equilibrium of blast furnace. (Online version in color.)

\section{Experimental Methods}

\subsection{Preparation of Various Agglomerates}

Four kinds of CA and two kinds of Ferro-coke were used in this study. Tables $\mathbf{1}$ and $\mathbf{2}$ show the chemical compositions and properties of these agglomerates.

The carbon composite agglomerate (CCA) is a CA with $1.2 \mathrm{C} / \mathrm{O}$ (bearing carbon to reducible oxygen in molar ratio). Industrial hematite powder $(66 \mathrm{wt} \%), 19 \mathrm{wt} \%$ of plant cokedust ( $83.5 \mathrm{wt} \%$ of F.C, $53 \mu \mathrm{m}$ of $\mathrm{d}_{50}$ and $250 \mu \mathrm{m}$ of top size) and $15 \mathrm{wt} \%$ of high-early-strength Portland cement (HPC, JIS R5210) were mixed, and then formed by an extruder. ${ }^{3)}$ Subsequently, the mixture was cured to obtain the CCA. Furthermore, RCA had a high $\mathrm{C} / \mathrm{O}$ (1.6) and was a commercialized CA made using dust. We also synthesized artificial coke pellet (ACP) in a laboratory for comparing their reactivity with that of RCA. Plant coke-dust ( $85 \mathrm{wt} \%$ ) and HPC (15 wt $\%$ ) were mixed, pelletized, and subsequently cured to obtain ACP. In addition, the carbon composite briquette (CCB) that contained M.Fe was prepared to analyze the influence of the M.Fe catalyst on the carbon reactivity of CA (Table 2). Fine iron ores, plant coke-dust, electrolytic iron powder (98\% purity), and HPC were used as raw materials, and their particle sizes $\left(\mathrm{d}_{50}\right)$ were $50,53,50$, and $13 \mu \mathrm{m}$, respectively. The raw materials were mixed, formed into briquettes, and subsequently cured. The resulting briquettes ( $4 \mathrm{~cm}^{3}$ in volume) were immersed in a $\mathrm{KOH}$ solution for a predetermined time to obtain CCB.

\begin{tabular}{|c|c|c|c|c|c|c|c|c|}
\hline & T.Fe & M.Fe & $\mathrm{FeO}$ & T.C & $\mathrm{CW}$ & Moisture & $\begin{array}{l}\text { Crushing } \\
\text { strength }\end{array}$ & Porosity \\
\hline & $\mathrm{wt} \%$ & $\mathrm{wt} \%$ & $\mathrm{wt} \%$ & $\mathrm{wt} \%$ & $\mathrm{wt} \%$ & $\%$ & $\mathrm{~kg} /$ Piece & $\%$ \\
\hline CCB1 & 49.77 & 0.73 & 0.40 & 12.22 & 1.94 & 3.0 & 89.9 & 27.2 \\
\hline CCB2 & 42.50 & 0.41 & 0.26 & 20.85 & 1.67 & 3.3 & 80.5 & 25.6 \\
\hline CCB3 & 35.44 & 0.28 & 0.17 & 29.30 & 1.63 & 3.2 & 59.2 & 30.1 \\
\hline CCB4 & 51.50 & 6.61 & 0.17 & 13.02 & 1.91 & 2.7 & 99.8 & 24.8 \\
\hline CCB5 & 44.14 & 6.93 & 0.22 & 21.52 & 1.62 & 3.1 & 71.4 & 24.3 \\
\hline CCB6 & 35.96 & 6.19 & 0.29 & 30.79 & 1.55 & 2.5 & 35.8 & 26.1 \\
\hline
\end{tabular}

We made a normal Ferro-coke without pre-forming and a formed Ferro-coke. The manufacturing method was the same as that used in previous report. ${ }^{6)}$ Pulverized coal and

\begin{tabular}{|c|c|c|c|c|c|c|c|c|c|c|c|c|c|c|}
\hline & $\begin{array}{l}\text { T.Fe } \\
\mathrm{wt} \%\end{array}$ & $\begin{array}{l}\text { M.Fe } \\
\mathrm{wt}^{\circ} \%\end{array}$ & $\begin{array}{l}\mathrm{FeO} \\
\mathrm{wt} \%\end{array}$ & $\begin{array}{c}\text { Ash } \\
\text { wt\%dry }\end{array}$ & $\begin{array}{l}\mathrm{CaO} \\
\mathrm{wt} \%\end{array}$ & $\begin{array}{l}\mathrm{SiO}_{2} \\
\mathrm{wt} \%\end{array}$ & $\begin{array}{l}\mathrm{Al}_{2} \mathrm{O}_{3} \\
\mathrm{wt}^{\circ} \%\end{array}$ & $\begin{array}{l}\mathrm{MgO} \\
\mathrm{wt}^{\circ} \% \\
\end{array}$ & $\begin{array}{c}\mathrm{Na}_{2} \mathrm{O}+\mathrm{K}_{2} \mathrm{O} \\
\mathrm{wt} \%\end{array}$ & $\begin{array}{c}\text { VM } \\
\text { wt\%dry }\end{array}$ & $\begin{array}{r}\text { T.C } \\
\mathrm{wt} \%\end{array}$ & $\begin{array}{c}\text { F.C } \\
\text { wt\%dry }\end{array}$ & $\begin{array}{l}\text { True density } \\
\mathrm{g} / \mathrm{cm}^{3}\end{array}$ & $\begin{array}{c}\text { Porosity } \\
\% \\
\end{array}$ \\
\hline CCA & 42.25 & $\operatorname{tr}$ & 0.33 & - & 9.83 & 4.06 & 1.36 & 0.43 & n.a. & - & 16.63 & - & 3.32 & 39.9 \\
\hline $\mathrm{RCA}$ & 35.11 & 0.23 & 2.47 & - & 10.96 & 6.35 & 2.61 & 0.68 & 0.15 & - & 17.97 & - & 3.14 & 24.9 \\
\hline $\mathrm{ACP}$ & 1.78 & $\operatorname{tr}$ & n.a. & - & 11.72 & 8.32 & 2.79 & 0.67 & 0.25 & - & 71.00 & - & 1.98 & 38.3 \\
\hline Sintered ore & 58.71 & $\operatorname{tr}$ & 7.18 & - & 9.25 & 4.92 & 1.62 & 0.72 & n.a. & - & $\operatorname{tr}$ & - & 4.66 & 22.5 \\
\hline FC3 & 8.46 & 6.17 & 1.21 & 20.84 & 0.11 & 6.04 & 3.35 & 0.08 & 0.15 & 0.00 & - & $79.16^{*}$ & 1.96 & 46.4 \\
\hline FC6 & 27.03 & 19.74 & 4.30 & 40.09 & 0.23 & 5.32 & 2.47 & 0.09 & 0.13 & 0.00 & - & $59.91^{*}$ & 2.31 & 45.3 \\
\hline Coke & $\operatorname{tr}$ & $\operatorname{tr}$ & $\operatorname{tr}$ & 11.27 & - & - & - & - & - & 0.94 & - & 87.79 & 1.98 & 44.6 \\
\hline
\end{tabular}

Table 2. Chemical compositions and properties of CCB.

Table 1. Chemical compositions and properties of agglomerates, sintered ore, and coke used in this study (tr: trace, n.a.: not analyzed, *: after consideration of oxidation during ash measurement). 
the iron ores of $10 \mathrm{wt} \%$ were mixed and carbonized in a test coke oven to obtain FC3. Pulverized coal and the iron ores of $30 \mathrm{wt} \%$ were mixed and formed into briquettes, and subsequently carbonized to obtain FC6.

Plant-sintered ores (10-15 $\mathrm{mm}$ in size) were mixed with the agglomerates. A plant coke (10.0-12.7 mm in size) was used as a reference.

\subsection{Softening-melting Test}

Generally, CA is mixed in ore layers in the blast furnace. Therefore, the reduction behaviors of the mixed ore layers with sintered ores and CCA were evaluated using a softening-melting tester. ${ }^{10)}$ The particle sizes of the sintered ores and CCA were $10-15 \mathrm{~mm}$. The test conditions were the same as those in the previous report. ${ }^{10)}$ The samples were charged to form a $70 \mathrm{~mm}$-high layer between the 20 mm-high coke layers in the graphite crucible. The samples were then heated to $800^{\circ} \mathrm{C}$ in the presence of $\mathrm{N}_{2}$ and, subsequently, heated in the presence of a reducing gas mixture with the composition of $\mathrm{CO}(29.4 \%)-\mathrm{H}_{2}(3.6 \%)-\mathrm{N}_{2}(67.0 \%)$ with the superficial velocity of $10 \mathrm{~cm} / \mathrm{s}$. During the heating, the samples were subjected to a $98-\mathrm{kPa}$ load. Both the rate of carbon consumption ( $\mathrm{RCC}$ ) and carbon consumption ratio (CCR) were evaluated using Eqs. (5) and (6). In addition, reduction degree was similarly evaluated using Eq. (7).

$$
\begin{aligned}
& \operatorname{RCC}(\mathrm{g} / \mathrm{min})= \\
& \left(\left(C O_{O}+C O 2_{O}\right)-\left(C O_{I}+C O 2_{I}\right)\right) / 0.0224 \cdot 12 \\
& \operatorname{CCR}(\%)=\frac{\int_{0}^{t} R C C d t}{C_{\text {before }}} \cdot 100 \\
& \left(\left(C O_{O}+2 \cdot C O 2_{O}\right)-\left(C O_{I}+2 \cdot C O 2_{I}\right)\right) / 0.0224 \cdot 16^{\cdots}
\end{aligned}
$$

where $\mathrm{CO}_{\mathrm{O}}$ denotes the exhaust $\mathrm{CO}$ rate $\left(\mathrm{Nm}^{3} / \mathrm{min}\right), \mathrm{CO} 2_{\mathrm{O}}$ the exhaust $\mathrm{CO}_{2}$ rate $\left(\mathrm{Nm}^{3} / \mathrm{min}\right), \mathrm{CO}_{\text {I }}$ the inlet $\mathrm{CO}$ rate $\left(\mathrm{Nm}^{3} / \mathrm{min}\right), \mathrm{CO}_{2}$ the inlet $\mathrm{CO}_{2}$ rate $\left(\mathrm{Nm}^{3} / \mathrm{min}\right), \mathrm{C}_{\text {before }}$ the carbon amount before reaction $(\mathrm{g})$, and $\mathrm{O}$ the oxygenreduction rate $(\mathrm{g} / \mathrm{min})$.

The reduction degrees at $800^{\circ} \mathrm{C}, 1000^{\circ} \mathrm{C}$ and $1200^{\circ} \mathrm{C}$, carbon consumption until $1200^{\circ} \mathrm{C}, \mathrm{T}_{50}$ (the temperature at which shrinkage reached $50 \%$ ), $\mathrm{T}_{\mathrm{S}}$ (the temperature at which pressure drop reached $2.0 \mathrm{kPa}$ ), $\mathrm{dP}_{\mathrm{MAX}}$ (maximum pressure drop), and S-value (the time integral of pressure drop) were evaluated as a function of the CCA ratio in the mixed layers.

\subsection{Reactivity Test}

The carbon reactivities of the agglomerates were evaluated in two measurement conditions, CRT1 and CRT2, by performing a large-scale thermogravimetric analysis. ${ }^{7)}$ To that end, $200 \mathrm{~g}$ of the agglomerates with sizes of 10.0$12.7 \mathrm{~mm}$ was used. In CRT1, samples were heated until $1200^{\circ} \mathrm{C}$ at the heating rate of $10^{\circ} \mathrm{C} / \mathrm{min}$, and $0.02 \mathrm{Nm}^{3} /$ min of $\mathrm{CO}-\mathrm{CO}_{2}-50 \% \mathrm{~N}_{2}$ gas was flowed at a constant $\mathrm{CO}_{2} /$ $\left(\mathrm{CO}+\mathrm{CO}_{2}\right)$ ratio during the tests. In each test, the $\mathrm{CO}_{2} /$ $\left(\mathrm{CO}+\mathrm{CO}_{2}\right)$ ratio was varied from 0.05 to 0.5 . The $\mathrm{RCC}$ during the tests was evaluated using Eq. (5). The CCR of the agglomerates was evaluated using Eq. (8) on the basis of the chemical analysis of the agglomerates before and after the tests. Only the CCR of coke without iron was evaluated using Eq. (6) on the basis of the exhaust-gas analysis.

$$
C C R(\%)=\left(1-\frac{(T . C / T . F e)_{a f t e r}}{(T . C / T . F e)_{b e f o r e}}\right) \cdot 100
$$

The starting temperature of carbon consumption was defined as the temperature at which RCC exceeded 0.04 $\mathrm{gC} / \mathrm{min}$.

In CRT2, the carbon reactivities of the agglomerates under the gas condition demonstrating plant blast furnaces were evaluated. $0.02 \mathrm{Nm}^{3} / \mathrm{min}$ of $\mathrm{CO}-\mathrm{CO}_{2}-\mathrm{N}_{2}$ gas was flowed, and the concentrations of $\mathrm{CO}$ and $\mathrm{CO}_{2}$ were varied with temperature until $1200^{\circ} \mathrm{C}$ (Fig. 2). In these tests, exhaust-gas analysis should be avoided for ensuring precise evaluation, as both the heating rate and composition of the inlet gas changed with time during the test. Therefore, the carbon consumption was evaluated via factor analyzing of the weight loss after the test. While analyzing ACP and $\mathrm{RCA}$, the weight loss until $500^{\circ} \mathrm{C}$ was considered because of the dehydration of cement-hydrate and combined water. In the evaluation of $\mathrm{CCB}$, homogeneously mixed layers with $350 \mathrm{~g}$ of sintered ores and $150 \mathrm{~g}$ of CCB were evaluated.

\subsection{Process Estimation}

A previously conducted investigation ${ }^{7)}$ reported the reduction in the temperature of TRZ and the increase in shaft efficiency of the blast furnace upon using Ferro-coke by a counter-current reaction simulator, called $\mathrm{BIS}^{11)}$ in the non-alkali-recirculation condition. In this study, we estimated the process of the blast furnace by using CA or Ferro-coke, and CA+Ferro-coke in the alkali-recirculation condition. CCA and FC6 were mixed in the ore layers, and FC3 and FC6 were mixed in the coke layers. The particle sizes of CCA and Ferro-coke were $8-11 \mathrm{~mm}$ and 9-13 mm, respectively. The charged amounts of the sintered ores and coke were changed to attain the constant values of T.Fe and T.C in every charge. The replacement ratio of carbon (charged carbon of the agglomerates to the total carbon) was changed in the range of $30-100 \%$. The composition

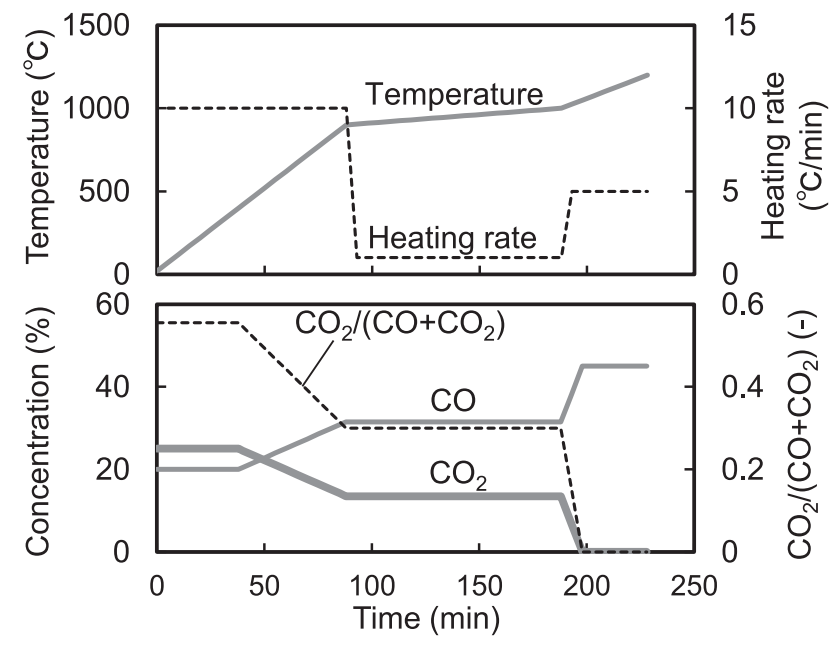

Fig. 2. Experimental conditions of the CRT2 test simulating blast furnace. 
(CO at $36.0 \%, \mathrm{H}_{2}$ at $7.0 \%, \mathrm{~N}_{2}$ at $57 \%$ ) and volume (1 343 $\mathrm{Nm}^{3} / \mathrm{t}-\mathrm{HM}$ ) of bosh gas were designed to demonstrate plant operation at the blast temperature of $1178^{\circ} \mathrm{C}$, blast moisture of $18.6 \mathrm{~g} / \mathrm{Nm}^{3}$, oxygen enrichment of $2.7 \%$ in RAR of 481 $\mathrm{kg} / \mathrm{t}-\mathrm{HM}$, and coke rate of $349 \mathrm{~kg} / \mathrm{t}-\mathrm{HM}$. Ore/coke was 4.63 . $\mathrm{KOH}$ (reagent grade) was added to coke to attain $1.8 \mathrm{wt} \%$ of $\mathrm{K}$ to demonstrate the recirculation of alkali within the plant (Appendix). The temperature at the minimum heating rate during the tests was defined as the temperature of TRZ.

\section{Results and Discussion}

\subsection{Behavior of Reduction and the Softening-melting of CCA}

Figure 3 shows the results of the softening-melting tests for different mixing ratios of CCA. The gasification of carbon initiated at $600^{\circ} \mathrm{C}$ and completed at $1100^{\circ} \mathrm{C}$ in a single use of CCA. However, the gasification of coke (at the top and the bottom of the ore layer) initiated at $1000^{\circ} \mathrm{C}$ in a single use of sintered ores. In addition, a rapid carbon consumption due to the smelting reduction during melting was also exhibited at $1210^{\circ} \mathrm{C}$. The reaction behavior observed upon mixing $40 \%$ of $\mathrm{CCA}$ to the sintered ores resembled that of CCA, rather than the middle of CCA and sintered ores. Figure 4 summarizes the results of softening- melting tests using CCA. The reduction degrees of the mixed layer increased with increasing the mixing ratio of CCA, particularly between 800 and $1000^{\circ} \mathrm{C}$ (a). The extent of the increase was larger than the extent of decrease of reducible oxygen with increasing the mixing ratio of CCA. The carbon consumption until $1200^{\circ} \mathrm{C}$ before smelting reduction also increased with increasing the mixing ration of CCA, implying the low-temperature gasification of carbon in CCA (b). Both reduction degrees and carbon consumption increased nonlinearly with increasing the mixing ratio of CCA, implying the synergistic effect due to mixing, i.e.,

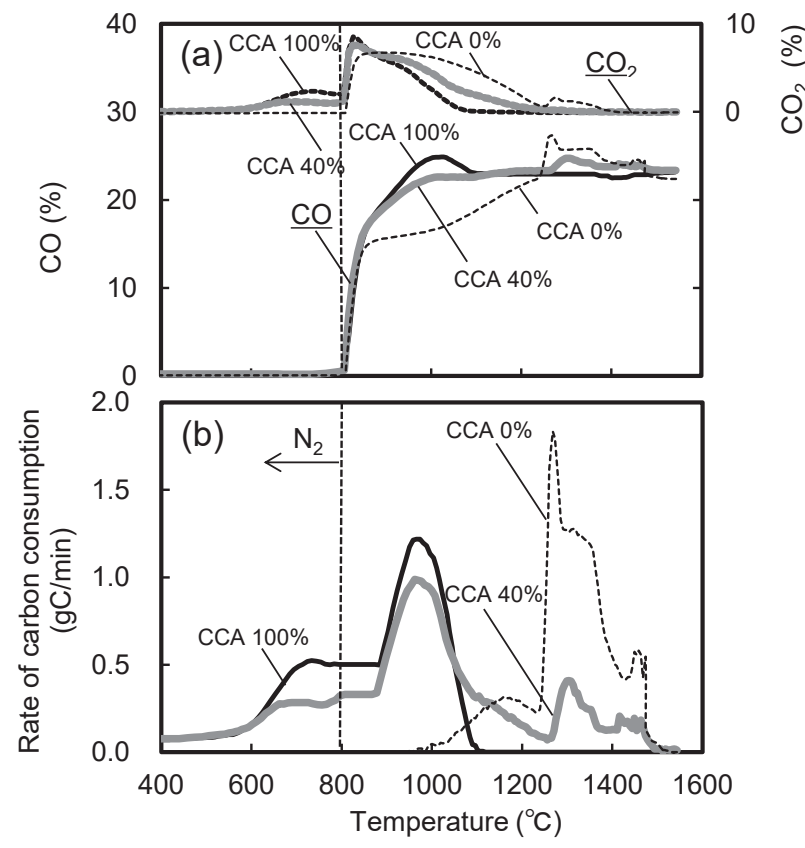

Fig. 3. Comparison of the composition of exhaust gas (a) and $\mathrm{RCC}$ in softening-melting tests with a different CCA ratio in ore layers. an enhancement in the reactivity of sintered ores or CCA. A similar synergistic effect was reported in a previously conducted investigation. ${ }^{12)}$ In addition, $\mathrm{T}_{50}$ decreased with increasing CCA, mostly because of the increase in the number of voids during gasification and reduction (c). However, $\mathrm{T}_{\mathrm{S}}$ increased and both $\mathrm{S}$-value and $\mathrm{dP}_{\mathrm{Max}}$ decreased with increasing CCA, mostly because of the decrease in the molten $\mathrm{FeO}$ near the melting temperature through an increase in the reduction degree $(\mathrm{d})$. However, both $\mathrm{S}$-value and $\mathrm{dP}_{\mathrm{Max}}$ increased again above for $80 \%$ of the mixing ratio of CCA because of an increase in slag volume. These results were in good agreement with those in past investigations. ${ }^{3,13)}$

\subsection{Carbon Reactivity of the Agglomerates}

3.2.1. Reactivity under iso- $\mathrm{CO}_{2} /\left(\mathrm{CO}+\mathrm{CO}_{2}\right)$ Condition (CRT1)

Figure 5 shows the results of the heating test using the agglomerates using 0.3 of $\mathrm{CO}_{2} /\left(\mathrm{CO}+\mathrm{CO}_{2}\right)$ of flow gas composition (CRT1). The carbon consumptions of Ferrocoke (FC6), RCA and ACP were higher than that of coke (b). The RCC values of RCA and ACP were low at below $950^{\circ} \mathrm{C}$, whereas their starting temperatures of the reaction were low at $700^{\circ} \mathrm{C}$. However, their rate of reaction became sufficiently high above $950^{\circ} \mathrm{C}$. Particularly, that of RCA containing iron oxide was higher than that of ACP without iron oxide, at temperatures above $1000^{\circ} \mathrm{C}$. During the heating of RCA, $\mathrm{CO}_{2}$ was observed to form due to reduction until $1000^{\circ} \mathrm{C}$, following which the formation of $\mathrm{CO}$ due to carbon gasification exceeded the $\mathrm{CO}_{2}$ formation (c).

Robinson $^{14)}$ observed the decomposition of $\mathrm{Ca}(\mathrm{OH})_{2}$, which is a product of cement hydration, followed by the water-gas reaction of carbon at $400-600^{\circ} \mathrm{C}$ during the heating of CA. We also observed $\mathrm{H}_{2}$ generation at $400-600^{\circ} \mathrm{C}$ during the heating of RCA and ACP; however, the gen-

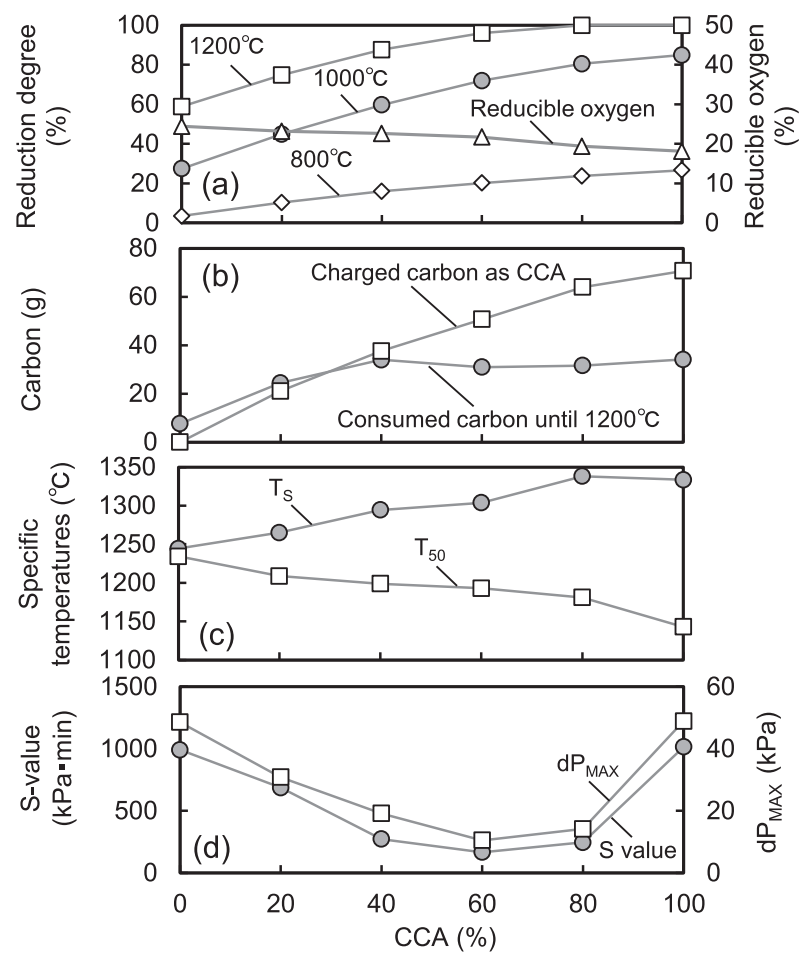

Fig. 4. Reduction behavior of ore layers with CCA and sinter as a function of CCA ratio in softening-melting tests. 


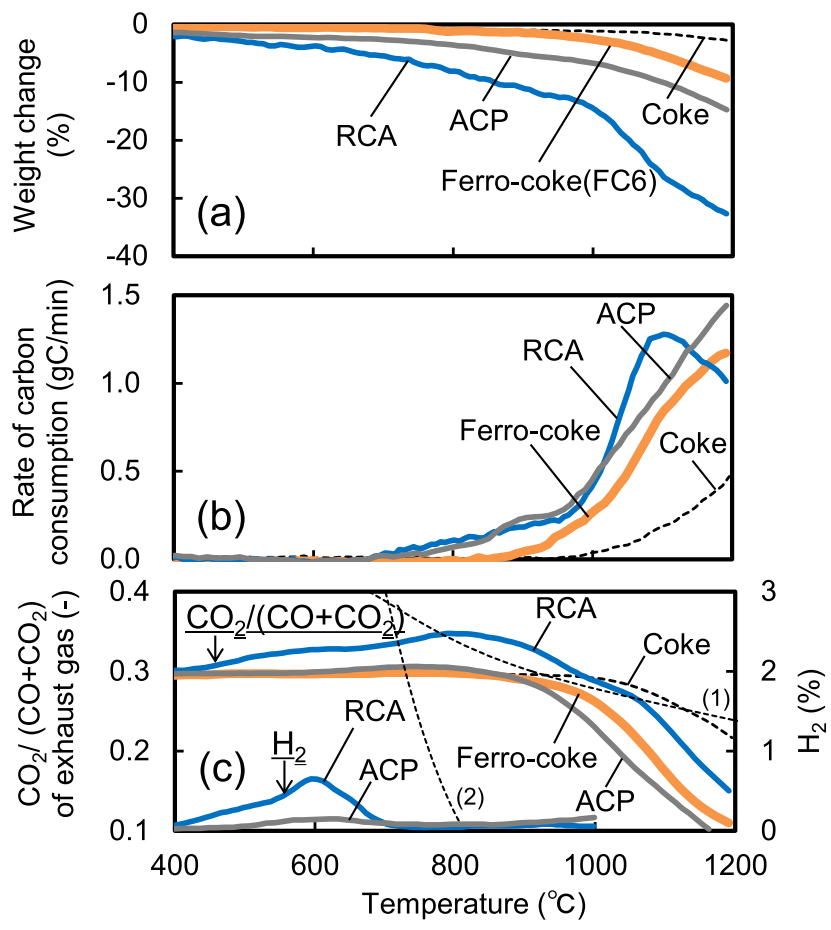

Fig. 5. Weight change (a), RCC (b), and compositions of exhaust gas (c) during heating tests with different agglomerates with the $\mathrm{CO}_{2} /\left(\mathrm{CO}+\mathrm{CO}_{2}\right)$ ratio of the inlet gas as 0.3 . (Online version in color.)

erated amount was insignificant (c). Watanabe et al. ${ }^{15)}$ observed the catalytic facilitation of carbon gasification near the gas composition in the equilibrium between $\mathrm{Fe}$ and $\mathrm{FeO}$ during the heating of CA consisting with ultra-fine iron oxide and biomass char. However, the facilitation of carbon gasification was not observed at $900^{\circ} \mathrm{C}$ during the heating of RCA, mostly because of the large size of iron oxide. Figure $\mathbf{6}$ shows the relationship between the starting temperature of carbon consumption and the composition of inlet gas during the heating of the agglomerates. The starting temperatures of all the agglomerates were lower than that of coke, and decreased with increasing the $\mathrm{CO}_{2} /\left(\mathrm{CO}+\mathrm{CO}_{2}\right)$ ratio. Ferrocoke had lower starting temperatures than that of coke, by $100-150^{\circ} \mathrm{C}$, thereby coinciding with the result of CIC. ${ }^{16)}$ The starting temperature of RCA was along the line showing the Boudouard equilibrium. Kawanari et al. ${ }^{17)}$ observed carbon gasification below $700^{\circ} \mathrm{C}$ during heating of CA with ultra-fine iron oxide and resin. However, carbon gasification at temperatures below that of the Boudouard equilibrium was not observed during the heating of RCA and ACP, as both comprised larger-sized iron oxide and coke.

Figure 7 shows the CCR and reduction degree of the agglomerates after reaction until $1200^{\circ} \mathrm{C}$ in CRT1. The CCRs of all the agglomerates were higher than that of coke and increased with increasing the $\mathrm{CO}_{2} /\left(\mathrm{CO}+\mathrm{CO}_{2}\right)$ ratio (a). Although the reduction degrees of Ferro-coke and RCA were lowered in conditions with higher $\mathrm{CO}_{2} /\left(\mathrm{CO}+\mathrm{CO}_{2}\right)$ ratio, they remained above $90 \%$, thereby showing the prevention of re-oxidation even in the stable-FeO condition (b).

These results showed that the carbon-consumption behaviors of the agglomerates varied significantly with the gas conditions, thereby implying the importance of designing their arrangement both along the radial and vertical direc-

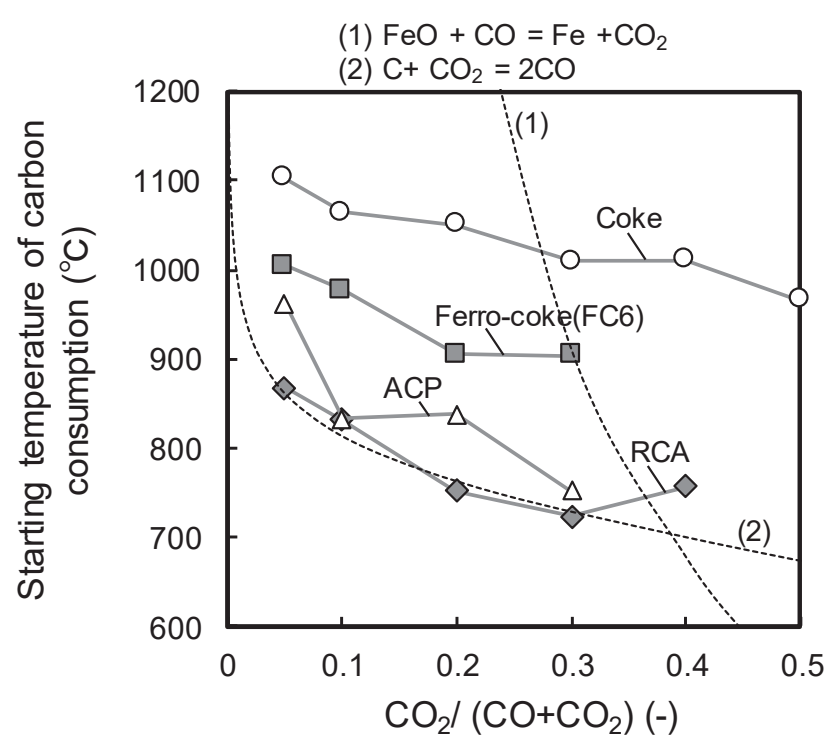

Fig. 6. Relationship between the starting temperature of carbon consumption and inlet-gas composition.

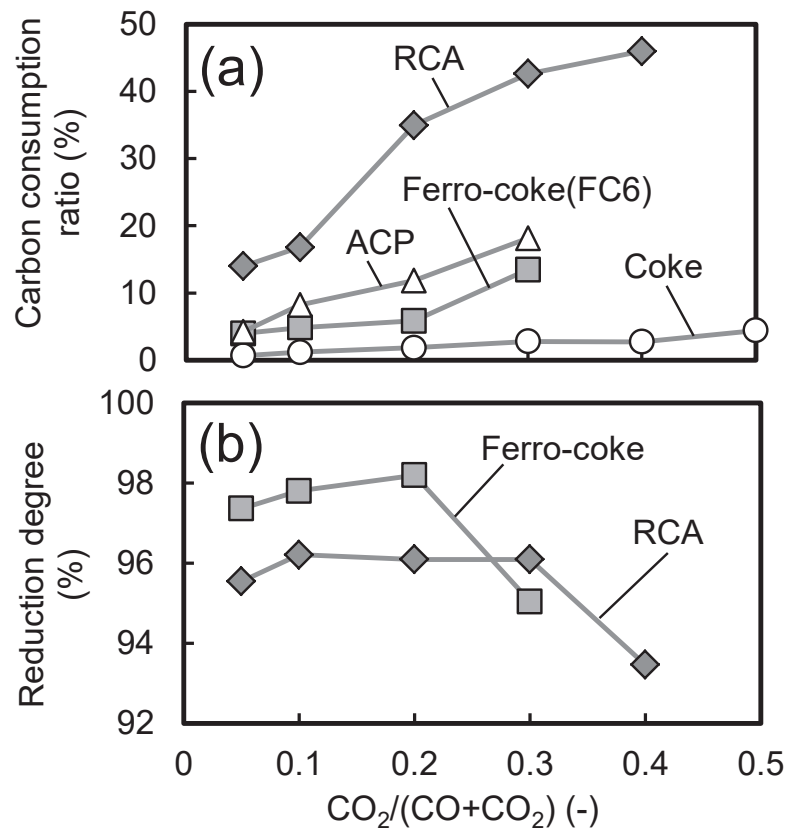

Fig. 7. Changes in CCR (a) and reduction degree (b) of the agglomerates after reaction until $1200^{\circ} \mathrm{C}$ with respect to inlet-gas composition.

tions in ore lyers.

\subsubsection{Reactivity under Plant Condition (CRT2)}

Figure 8 shows the results of the heating test using the agglomerates under the gas composition demonstrating plant (CRT2). Similar to the results shown in Fig. 5, the carbon consumptions of Ferro-coke (FC6), RCA and ACP were higher than that of coke (b). In addition, the formation of $\mathrm{CO}_{2}$ was also observed until $900^{\circ} \mathrm{C}$ during the heating of RCA (c).

Table 3 presents the result of the weight-loss analysis of the agglomerates after heating until $1200^{\circ} \mathrm{C}$ in CRT2. The carbon consumption of Ferro-coke was higher than that of coke, thereby coinciding with the results of past investiga- 


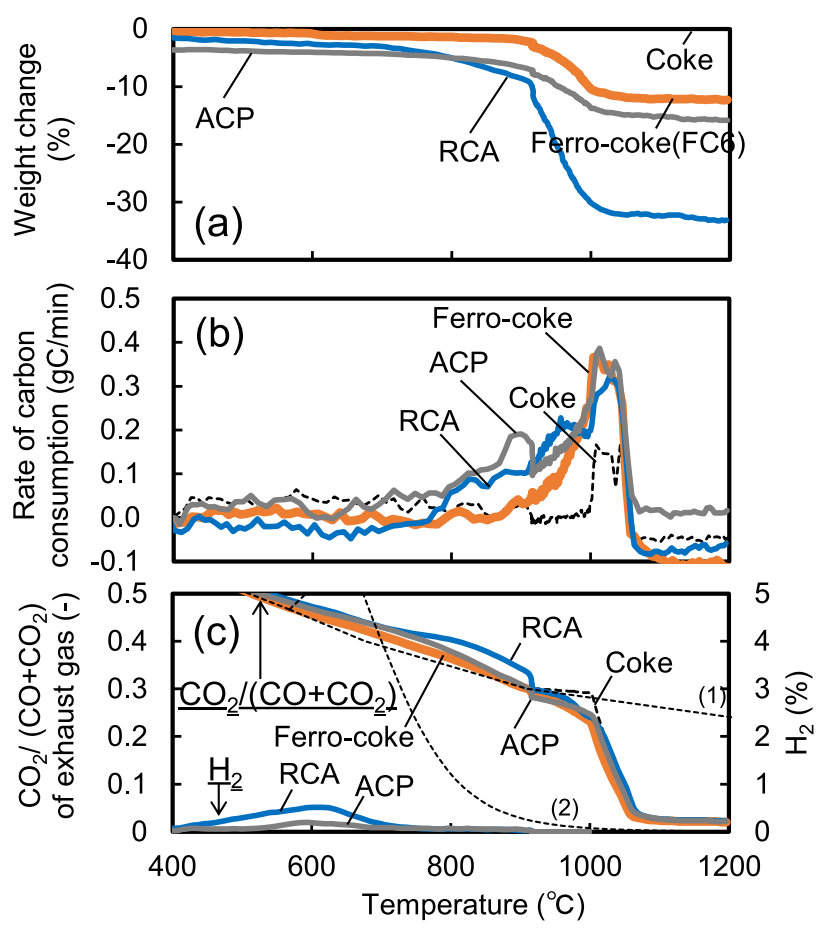

Fig. 8. Weight change (a), RCC (b), and exhaust-gas compositions (c) during heating tests with different agglomerates with respect to the gas composition of blast furnace. (Online version in color.)

Table 3. Results of the weight-loss analysis of the agglomerates after heating until $1200^{\circ} \mathrm{C}$ in CRT2.

\begin{tabular}{ccccccc}
\hline & & Coke & FC3 & FC6 & ACP & RCA \\
\hline $\begin{array}{l}\text { Carbon content } \\
\text { before reaction }\end{array}$ & $\mathrm{wt} \%$ & 87.0 & 79.2 & 59.9 & 71.0 & 18.0 \\
\hline \begin{tabular}{c} 
Weight loss \\
\hline Oxygen
\end{tabular} & $\mathrm{wt} \%$ & 0.5 & 5.8 & 12.3 & 15.8 & 33.3 \\
\hline Water & $\mathrm{wt} \%$ & 0.0 & 0.0 & 0.0 & 3.8 & 2.1 \\
\hline Carbon & $\mathrm{wt} \%$ & 0.5 & 4.9 & 9.7 & 12.0 & 16.6 \\
\hline $\begin{array}{l}\text { Carbon } \\
\text { consumption ratio }\end{array}$ & $\%$ & 0.5 & 6.2 & 16.1 & 16.9 & 92.6 \\
\hline
\end{tabular}

tions. ${ }^{18)}$ In addition, ACP presented higher carbon consumption, mostly because of the smaller size of carbon $^{19)}$ and catalytic effect of $\mathrm{Ca}^{20)}$ from cement. Furthermore, RCA had higher carbon reactivity. Because RCA and ACP had similar alkali contents (Table 1 ), the high carbon reactivity of RCA was mainly attributed to the coupling phenomena ${ }^{2)}$ due to the close arrangement of carbon and iron oxide.

\subsubsection{Influence of M.Fe in CAs}

The starting temperature of the carbon consumption of RCA increased with increasing the $\mathrm{CO}_{2} /\left(\mathrm{CO}+\mathrm{CO}_{2}\right)$ ratio from 0.3 to 0.4 , thereby implying that the reduction mechanism of the temperature was related with the formation of metallic iron during the heating (Fig. 6). A similar consideration was made in a past investigation. ${ }^{21)}$ Therefore, the reaction behavior of $\mathrm{CCB}$ with $\mathrm{M}$.Fe under plant condition (CRT2) was investigated to clarify the influence of M.Fe on the reaction of CA. Figure 9 shows the results achieved by evaluating the reactivity of CCB. Although the CCR of CCB
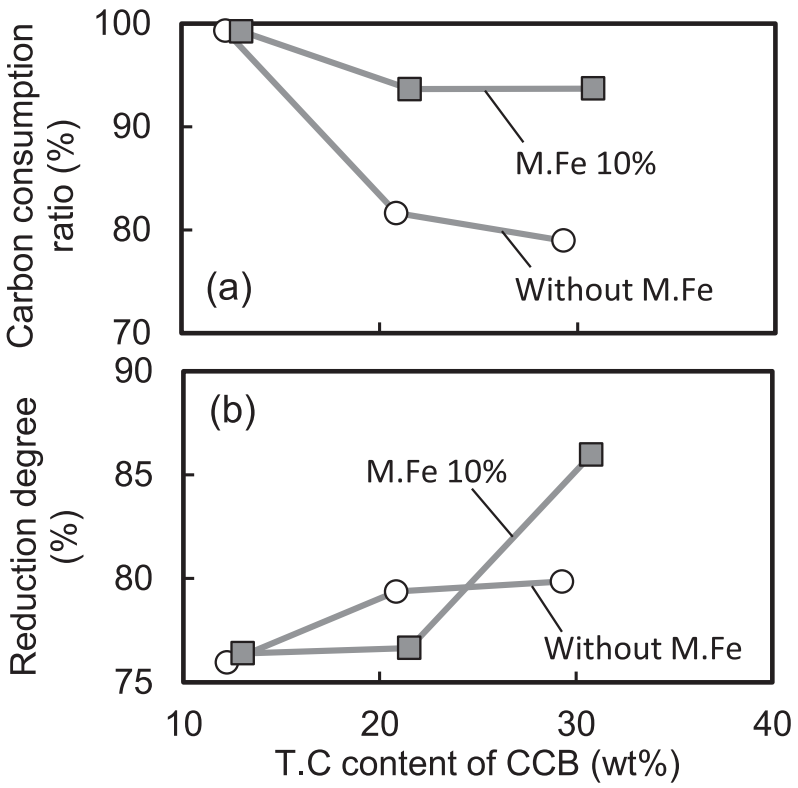

Fig. 9. Influence of the M.Fe addition to $\mathrm{CCB}$ on CCR (a) and reduction degree after heating ore layers with sinter (70 $w t \%)$ and CCB (30 wt $\%)$.

decreased with increasing the T.C content in CCB, the M.Fe addition enhanced it. The reduction degree of the ore layers were the highest at $30 \mathrm{wt} \%$ of T.C with M.Fe addition. From these results, it is concluded that the catalytic effect of M.Fe on coke reactivity could be effective not only in Ferro-coke but also in CA.

\subsection{Process Estimation of Blast Furnace Using the Agglomerates \\ 3.3.1. Process Estimation}

Table 4 presents the results of the BIS test, along with the RAR estimated using a mathematical model. ${ }^{22}$ ) Notably, $30 \%$ replacement of carbon by the CCA reduced the temperature of TRZ by $150^{\circ} \mathrm{C}$, thereby decreasing the RAR by $29 \mathrm{~kg} / \mathrm{t}-\mathrm{HM}$ even in the alkali-recirculation condition. The decrease corresponded to $0.3 \mathrm{~kg} / \mathrm{t}-\mathrm{HM}$ per $1 \mathrm{~kg} / \mathrm{t}-\mathrm{HM}$ of carbon from $\mathrm{CA}$, and was fairly smaller than those in the past investigations performed using smaller replacement ratios; i.e. $0.6,{ }^{23)} 0.4,{ }^{13)} 0.5^{24)}$ and $0.4 .^{4)}$ The result implied that the RAR-decreasing efficiency by CA depended on the amount of CA used. The estimated RAR of the blast furnace using FC6 in full replacement was similar to that using CCA caused by the effect of M.Fe charging, whereas the temperature of the TRZ was limited to $915^{\circ} \mathrm{C}$. The combination of $\mathrm{CA}$ and Ferro-coke was examined to further reduce RAR. Mixing CCA in the ore layer by $30 \%$ replacement and simultaneously mixing FC6 in the coke layer by $35 \%$ replacement decreased the temperature of the TRZ to $842^{\circ} \mathrm{C}$, thereby resulting in $466 \mathrm{~kg} / \mathrm{t}-\mathrm{HM}$ of the estimated RAR. A check test was performed by decreasing the RAR by $35 \mathrm{~kg} / \mathrm{t}-\mathrm{HM}$, corresponding to the increase of charging $\mathrm{Fe} / \mathrm{C}$ from 3.06 to 3.33 and the reduction of the bosh gas volume from 1343 to $1174 \mathrm{~kg} / \mathrm{t}-\mathrm{HM}$. The heating and reduction behaviors of ores in the low-RAR condition were similar to those in the high-RAR condition (Fig. 10), thereby confirming the validity of the estimation. However, the decrease in the top gas temperature upon using a signifi- 
Table 4. Results of the BIS tests using the agglomerates.

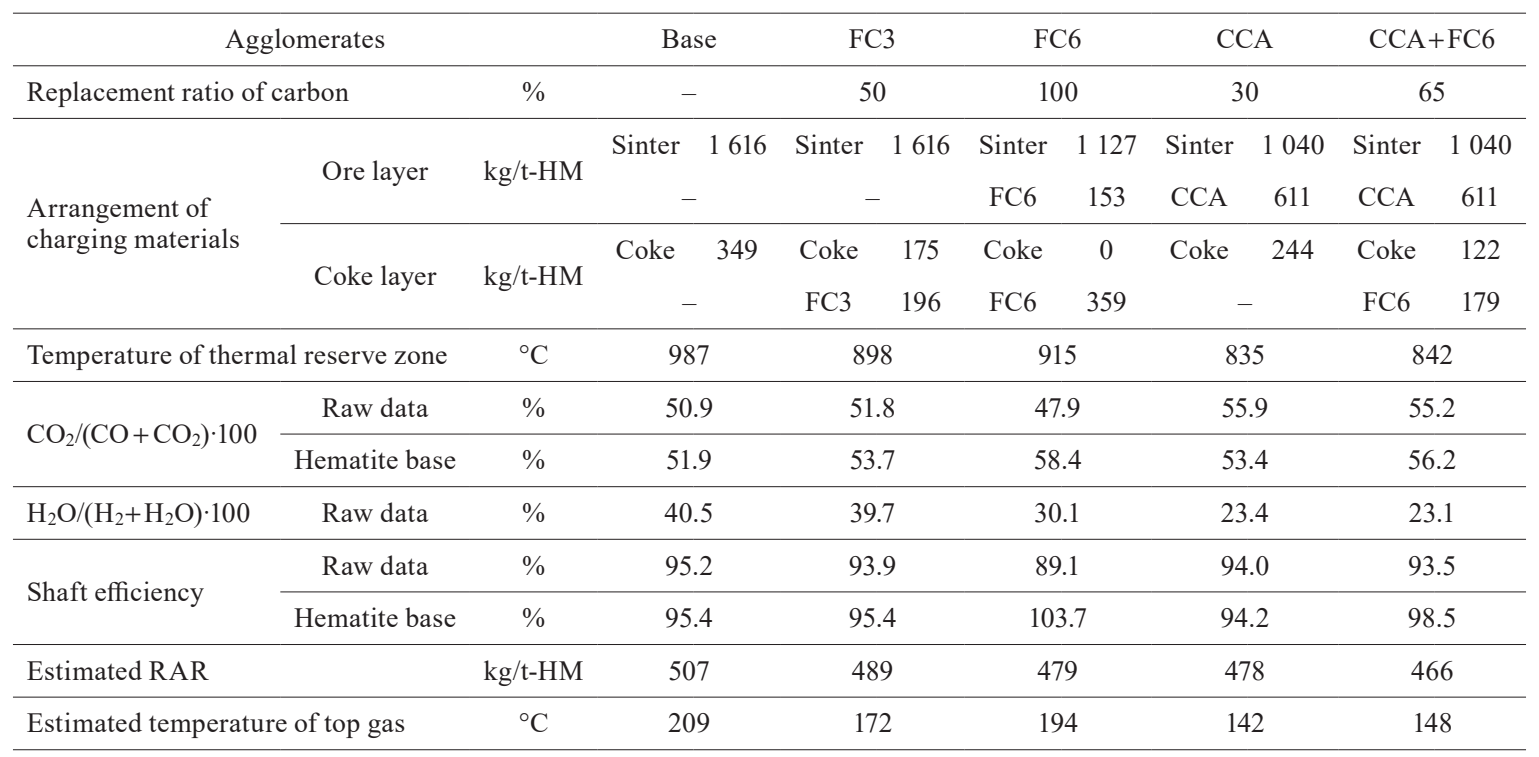

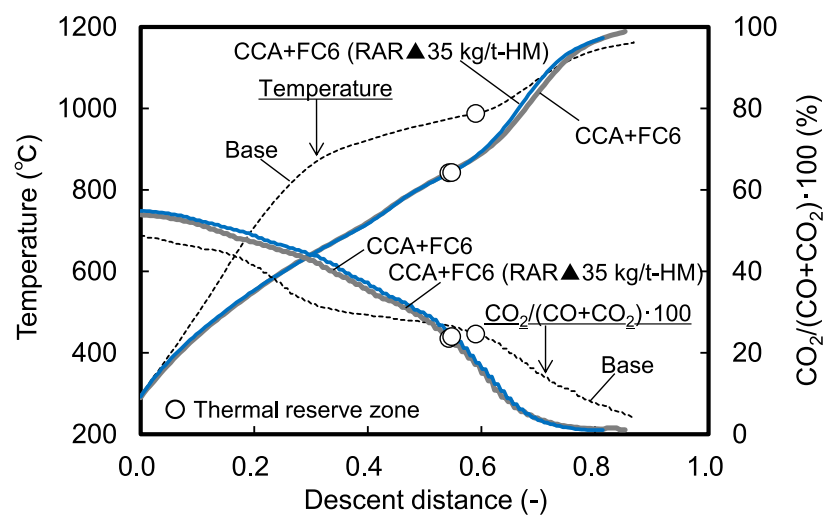

Fig. 10. Changes in temperature and gas composition during the BIS test with CCA and Formed Ferro-coke (FC6) (Online version in color.)

cant quantity of these agglomerates (Table 4) would be one of the factors limiting their use, in addition to their physical properties related to the permeability of the blast furnace.

\subsubsection{Reaction Behavior of the Agglomerates during the BIS Test}

Figure 11 shows the relationship between CCR and the reduction degree of CCA during the BIS test, together with the molar ratios of consumed carbon to reduced oxygen. Because CCA was completely reduced at low temperature $\left(1035^{\circ} \mathrm{C}\right)$, the carbon consumption was assumed to occur only because of gasification until the end of reduction, by referring to past investigations that reported a slight carburization of the formed iron, i.e., $2.0 \mathrm{wt} \%$ at $1300^{\circ} \mathrm{C}^{25)}$ and 0.1 $\mathrm{wt} \%$ at $1100^{\circ} \mathrm{C}^{26)}$ The insignificant vales of carbon consumption until achieving $30 \%$ of reduction degree showed that CCA was reduced only by $\mathrm{CO}$ in the surrounding bulk gas. For above $30 \%$ of reduction degree, both carbon consumption and reduction proceeded simultaneously to attain $1.0 \mathrm{C} / \mathrm{O}$. This finding proved the self-reduction with coupling phenomena within CCA, and was in agreement with the assumption by Ueda et al. ${ }^{19)}$ They assumed gas reduction at the initial stage and the self-reduction at the

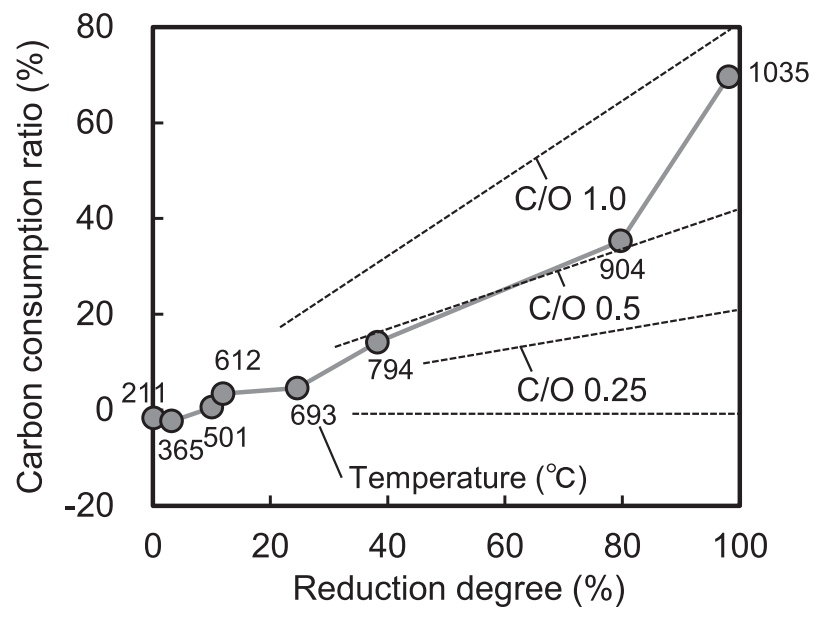

Fig. 11. Relationship between CCR and the reduction degree of $\mathrm{CCA}$ in the BIS test. The numerical values represent temperatures.

later stage, during the reaction of $\mathrm{CA}$ in a reaction model.

Figure 12 shows the analysis result of the agglomerates after quenching during the BIS test, for the combination of CCA and FC6. The reduction degree of CCA was higher than that of the coexisting sintered ores (a). The higher reduction degree of coexisting sintered ores compared with that in base condition without agglomerates showed the shift in reduction equilibrium ( $\mathrm{W}$ point) due to the reduction in the temperature of TRZ. FC6 represented a partial re-oxidation between 500 and $800^{\circ} \mathrm{C}$. First, the carbon consumption of CCA initiated, followed by that of FC6 followed (b). The ash contents of coke during the test were similar to those in the base condition without agglomerates, thereby showing limited reaction of coke (c). The result showed that the coke gasification was prevented by other high-reactivity carbonaceous materials. ${ }^{6}$

\subsection{Influence of the Distance between Carbon and Iron Oxide on the Temperature of TRZ}

Although all the agglomerates showed higher carbon 


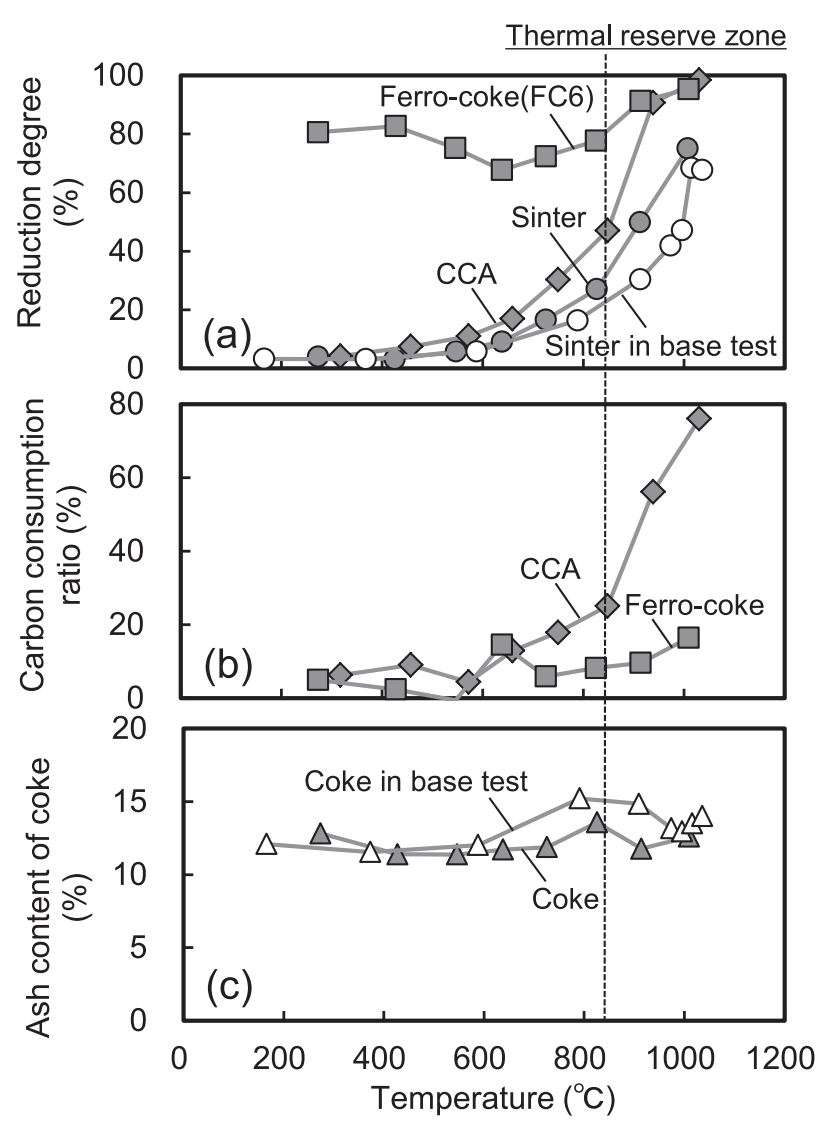

Fig. 12. Reduction degree (a) and CCR (b) of charged agglomerates and the ash content of coexisting conventional coke (c) in the BIS test with CCA and FC6.

reactivities than that of coke, their reactivities were different from each other. Therefore, the reasons for the difference among reactivities were discussed on the basis of the distance between carbon and iron oxide or metallic iron (hereafter denoted as only "iron oxide"). The average distance between carbon and iron oxide $\left(\mathrm{L}_{\mathrm{OC}}\right)$ and the surface area of carbon were estimated for all the agglomerates. The following were the assumptions of the conventional charging condition; layer-by-layer charging ores and coke, coke diameter of $40 \mathrm{~mm}$, and coke-layer thickness of $360 \mathrm{~mm}$. For reference, the properties for half the aforementioned coke-layer thickness, completely mixing coke and ores, and mixing nut-coke $(20 \mathrm{~mm})$ were also estimated.

L ${ }_{\mathrm{OC}}$ was estimated using Eqs. (9) and (10) by approximating a spherical unit. The unit contained a core of one carbon particle in the case of CA and mixing coke, and it contained a core of one particle of metallic iron in the case of Ferro-coke. The following equations show the case of $\mathrm{CA}$ and mixing coke.

$$
\begin{gathered}
L_{O C}(m m)=\frac{\int_{d_{C} / 2}^{d_{U} / 2} x^{3} d x}{\int_{d_{C} / 2}^{d_{U} / 2} x^{2} d x}-\frac{d_{C}}{2} \\
d_{U}(m m)=d_{C} \cdot\left(1+\frac{V_{O}}{V_{C}}\right)^{1 / 3}
\end{gathered}
$$

where $\mathrm{d}$ denotes the diameter $(\mathrm{mm}), \mathrm{V}$ the volume $\left(\mathrm{mm}^{3}\right)$, subscript $\mathrm{U}$ the spherical unit, subscript $\mathrm{O}$ the iron ores, and

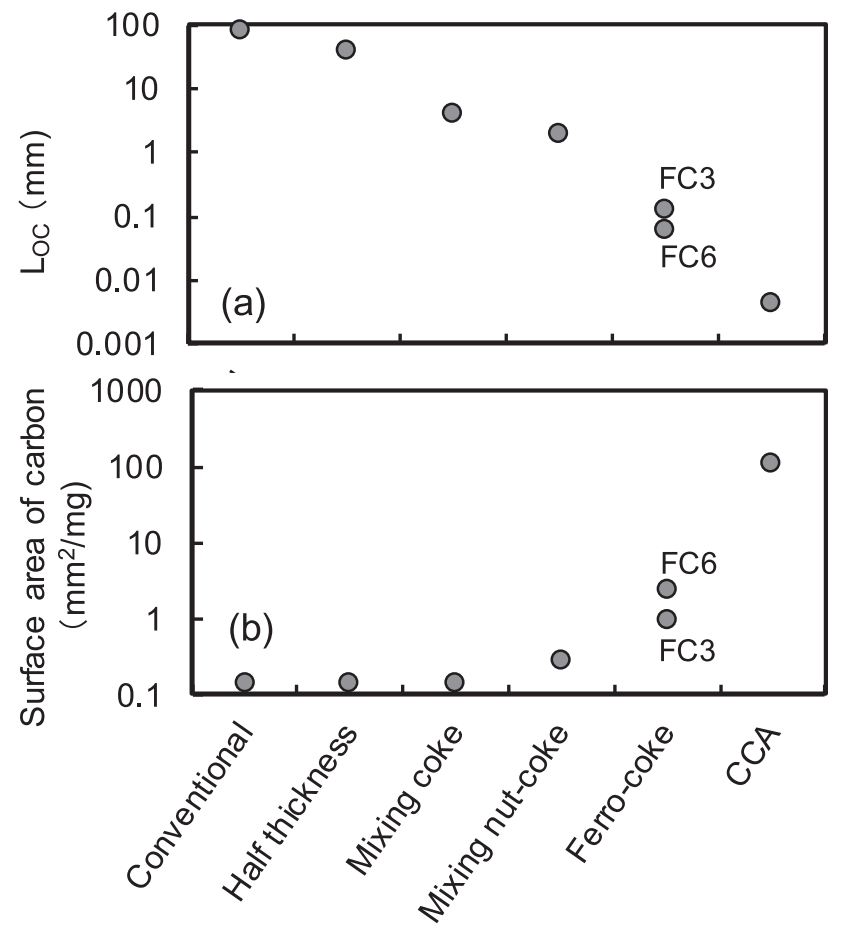

Fig. 13. Evaluation results of $\mathrm{L}_{\mathrm{OC}}$ (average distance between iron oxide and carbon (a)) and surface area of coke (b) along different charging conditions.

subscript $\mathrm{C}$ the coke. The contents of iron oxide and carbon in CCA were converted to iron ores and coke, respectively. In addition, the bulk densities of the ores and coke were 1.6 and $0.5 \mathrm{mg} / \mathrm{mm}^{3}$, respectively. During the estimation of Ferro-coke, the true densities of M.Fe $\left(\rho_{\mathrm{tM}}\right)$ and FeO $\left(\rho_{\mathrm{tFeO}}\right)$, and the apparent density of coke $\left(\rho_{\text {apC }} 1.1 \mathrm{mg} / \mathrm{mm}^{3}\right)$ were used. Because the metallic iron in Ferro-coke was homogeneously distributed in the coke matrix without aggregation, ${ }^{7)}$ the diameter of metallic iron $\left(\mathrm{d}_{\mathrm{M}}\right)$ was used as $0.09 \mathrm{~mm}$, by considering the shrinkage of charged iron oxide $(0.12 \mathrm{~mm}$ in the median size) based on the increase of theoretical true density from 5.16 to $7.43 \mathrm{mg} / \mathrm{mm}^{3}$ during the carbonization. The surface of the carbon in CCA $\left(\mathrm{A}_{\mathrm{C}}\right)$ was estimated using Eq. (11). The surface of the carbon in Ferro-coke $\left(A_{F C}\right)$, including the contact interface area between metallic iron and coke, was estimated using Eq. (12).

$$
\begin{aligned}
& A_{C}\left(m m^{2} / m g\right)=\frac{6}{d_{C}} \cdot \frac{1}{\rho_{a p C}} . \\
& A_{F C}\left(m m^{2} / m g\right)=\frac{6}{d_{F C}} \cdot \frac{1}{\rho_{a p F C}} \\
& +\frac{6}{d_{M}} \cdot\left(\frac{W_{M}}{100 \cdot \rho_{t M}}+\frac{W_{F e O}}{100 \cdot \rho_{t F e O}}\right)
\end{aligned}
$$

where, $\mathrm{W}$ denotes the weight ( $\mathrm{wt} \%), \rho_{\mathrm{ap}}$ the apparent density $\left(\mathrm{mg} / \mathrm{mm}^{3}\right)$, subscript FC the Ferro-coke, subscript $\mathrm{M}$ the Metal, subscript FeO the FeO. The measured $\rho_{\text {ap }}$ for FC3 was 1.05 and that for FC6 was 1.22.

Figure 13 shows the estimation results of $\mathrm{L}_{\mathrm{OC}}$ and surface area of carbon. Although high $\mathrm{L}_{\mathrm{OC}}$ was estimated for the conventional layer-by-layer charging without agglomerations, thinning the coke layer decreased $\mathrm{L}_{\mathrm{OC}}$. Complete mix- 

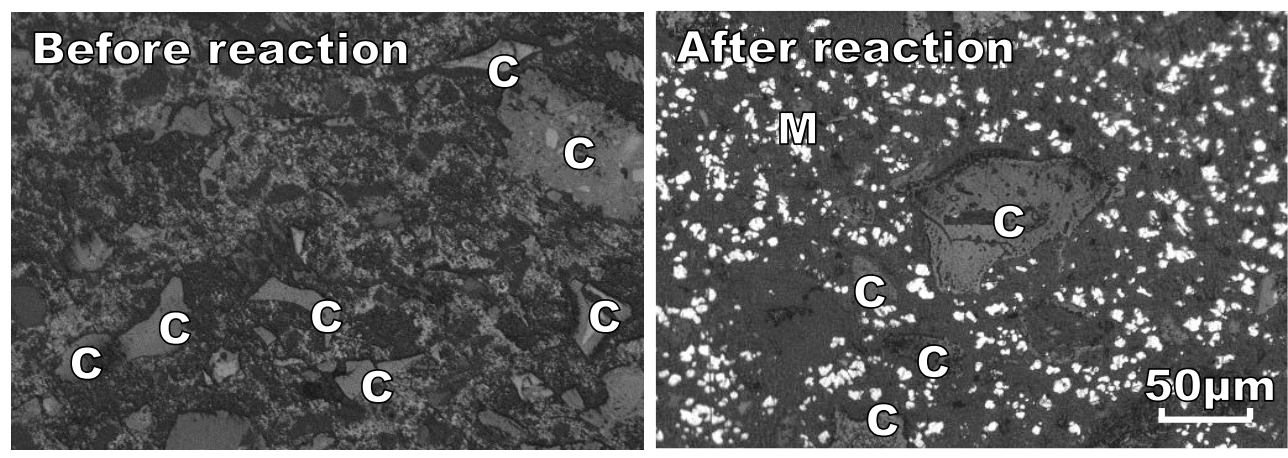

Fig. 14. Microstructures of CCA before and after reaction (quenched temperature: $904^{\circ} \mathrm{C}$, reduction degree: $80 \%, \mathrm{CCR}$ : $35 \%)$. C (gray): Coke, M (white): Metal.

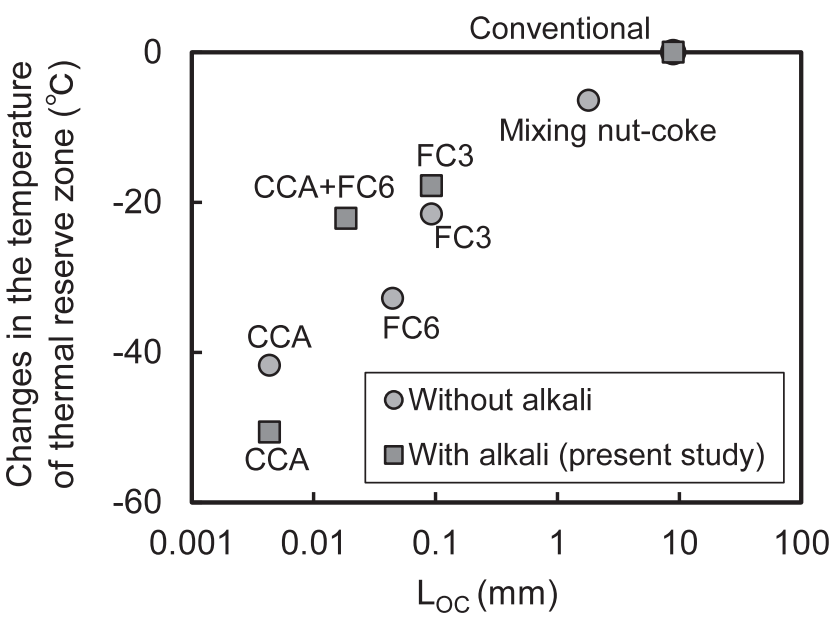

Fig. 15. Relationship between changes in the temperature of TRZ (results of the BIS test) and $\mathrm{L}_{O C}$ (average distance between iron oxide and carbon).

ing further reduced $\mathrm{L}_{\mathrm{OC}}$, and nut-coke enhanced the reduction and improved the surface area of carbon. Compared with these changes, the agglomerates significantly decreased $\mathrm{L}_{\mathrm{OC}}$ and increased the surface area of carbon. Figure 14 shows the microstructures of CCA before and after the BIS test. The structure of CCA had the structure with coarse coke-dust particles embedded in fine iron oxide particles, showing several microns order of $\mathrm{L}_{\mathrm{OC}}$ before reaction. The structure of CCA quenched at $904^{\circ} \mathrm{C}$ during the BIS test had the structure with residual carbon particles and fine metallic iron, thereby also showing several microns order of $\mathrm{L}_{\mathrm{OC}}$.

Figure 15 shows the relationship between the reduction in the temperature of TRZ in the BIS tests and $\mathrm{L}_{\mathrm{OC}}$ in the cases of both mixing nut-coke and using the agglomerates in the limited replacement ratio with carbon less than $50 \%$. The results of a past investigation without the alkali addi$\operatorname{tion}^{3,7)}$ are also shown in the figure. The condition of mixing nut-coke was the homogeneously mixing of $175 \mathrm{~kg} / \mathrm{t}-\mathrm{HM}$ of coke with $9-13 \mathrm{~mm}$ of size to the ore layer. As the replacement ratios of carbon were different in the tests, the reduction of temperature of TRZ at $10 \%$ replacement of carbon was evaluated. The temperature of TRZ decreased with decreasing $\mathrm{L}_{\mathrm{OC}}$. This finding agreed with the past investigation by Kasai et al. ${ }^{27)}$ They also observed a larger decrease in the starting temperature of endothermic reactions by CA compared with that observed upon mixing nut-coke. The influence of alkali addition on the evaluation of various agglomerates was insignificant, which was consistent with the results in a previously conducted investigation. ${ }^{6}$ The dominant factor reducing the temperature of TRZ was the distance between carbon and iron oxide.

\section{Conclusions}

To decrease the RAR of blast furnaces, the reaction behaviors of CAs and Ferro-coke with high carbon reactivity were evaluated, and consequently, process estimation of a blast furnace was performed. The following results were obtained.

(1) CAs exhibited low-temperature gasification, thereby facilitating reduction upon mixing with sintered ores.

(2) The CCRs until $1200^{\circ} \mathrm{C}$ of CAs and Ferro-coke were higher than that of coke. Particularly, RCA, which is reinforced CAs with high carbon content toward reducing the RAR, exhibited low starting temperature of the carbon consumption and high carbon reactivity during heating. The high carbon reactivity of RCA was primarily attributed to the coupling phenomena between gas reduction of iron oxide and gasification of carbon.

(3) Adding metallic iron to the $\mathrm{CA}$ resulted in the enhancement of carbon consumption and reduction of the sintered ores due to the catalytic effect of metallic iron.

(4) A combined use of the CA and Ferro-coke in the blast furnace reduced the temperature of TRZ by $150^{\circ} \mathrm{C}$, thereby giving a potential to decrease RAR by $35 \mathrm{~kg} / \mathrm{t}-\mathrm{HM}$.

(5) The reduction of the temperature of TRZ due to the $\mathrm{CA}$ and Ferro-coke was closely associated with shortening the distance between carbon and iron oxide or metallic iron.

\section{Acknowledgement}

A part of this study was conducted as a part of the research activities "Fundamental Study on Next Innovative Iron Making Process" programmed for the project "Strategic Development of Energy Conservation Technology Project". The financial support from New Energy and Industrial Technology Development Organization (NEDO) is gratefully acknowledged.

\section{REFERENCES}

1) Ministry of the Environment Government of Japan: Japan's National Greenhouse Gas Emissions in Fiscal Year 2018 (Preliminary Figures), https://www.env.go.jp/en/headline/2420.html, (accessed 201912-26).

2) Y. Kashiwaya, M. Kanbe and K. Ishii: ISIJ Int., 46 (2006), 1610. 
https://doi.org/10.2355/isijinternational.46.1610

3) M. Nakano, M. Naito, K. Higuchi and K. Morimoto: ISIJ Int., 44 (2004), 2079. https://doi.org/10.2355/isijinternational.44.2079

4) H. Yokoyama, K. Higuchi, T. Ito and A. Oshio: ISIJ Int., 52 (2012), 2000. https://doi.org/10.2355/isijinternational.52.2000

5) K. Higuchi, H. Yokoyama, H. Sato, M. Chiba and S. Nomura: ISIJ Int., 57 (2017), 55. https://doi.org/10.2355/isijinternational. ISIJINT-2016-418

6) S. Nomura, K. Higuchi, K. Kunitomo and M. Naito: ISIJ Int., 50 (2010), 1388. https://doi.org/10.2355/isijinternational.50.1388

7) K. Higuchi, S. Nomura, K. Kunitomo, H. Yokoyama and M. Naito: ISIJ Int., 51 (2011), 1308. https://doi.org/10.2355/isijinternational.51.1308

8) H. Ohme and T. Suzuki: Energy Fuels, 10 (1996), 980. https://doi. org/10.1021/ef950255b

9) M. Sato, H. Matsuno and K. Ishii: Proc. Asia Steel Int. Conf. 2015 (Asia Steel 2015), ISIJ, Tokyo, (2015), 12.

10) K. Higuchi, M. Naito, M. Nakano and Y. Takamoto: ISIJ Int., 44 (2004), 2057. https://doi.org/10.2355/isijinternational.44.2057

11) M. Naito, A. Okamoto, K. Yamaguchi, T. Yamaguchi and Y. Inoue: Tetsu-to-Hagané, 87 (2001), 357 (in Japanese). https://doi. org/10.2355/tetsutohagane1955.87.5_357

12) H. Mizoguchi, H. Suzuki and S. Hayashi: ISIJ Int., 51 (2011), 1247. https://doi.org/10.2355/isijinternational.51.1247

13) M. Chu, Z. Liu, Z. Wang and J. Yagi: Steel Res. Int., 82 (2011), 521 https://doi.org/10.1002/srin.201100044

14) R. Robinson: Thermochim. Acta, 432 (2005), 112. https://doi. org/10.1016/j.tca.2005.04.015

15) K. Watanabe, S. Ueda, R. Inoue and T. Ariyama: ISIJ Int., 50 (2010), 524. https://doi.org/10.2355/isijinternational.50.524

16) T. Yamamoto, T. Sato, H. Fujimoto, T. Anyashiki, K. Fukada, M. Sato, K. Takeda and T. Ariyama: Tetsu-to-Hagané, 97 (2011), 501 (in Japanese). https://doi.org/10.2355/tetsutohagane.97.501

17) M. Kawanari, A. Matsumoto, R. Ashida and K. Miura: ISIJ Int., 51 (2011), 1227. https://doi.org/10.2355/isijinternational.51.1227

18) K. Nishioka, Y. Ujisawa and T. Inada: Tetsu-to-Hagané, 100 (2014), 1347 (in Japanese). https://doi.org/10.2355/tetsutohagane.100.1347

19) S. Ueda, K. Yanagiya, K. Watanabe, T. Murakami, R. Inoue and T. Ariyama: ISIJ Int., 49 (2009), 827. https://doi.org/10.2355/ isijinternational.49.827

20) S. Nomura, H. Kitaguchi, K. Yamaguchi and M. Naito: ISIJ Int., 47 (2007), 245. https://doi.org/10.2355/isijinternational.47.245

21) F. Meng, Y. Iguchi and S. Hayashi: Tetsu-to-Hagané, 88 (2002), 479 (in Japanese). https://doi.org/10.2355/tetsutohagane1955.88.9_479

22) M. Naito and T. Nishimura: Proc. Asia Steel Int. Conf., Vol. B, CSM, Beijing, (2000), 268.

23) R. Robinson and L. S. Ökvist: Steel Res. Int., 75 (2004), 99. https:// doi.org/10.1002/srin.200405934

24) A. Kasai, H. Toyota, K. Nozawa and S. Kitayama: ISIJ Int., 51 (2011), 1333. https://doi.org/10.2355/isijinternational.51.1333

25) T. Murakami, M. Ohno, K. Suzuki, K. Owaki and E. Kasai: ISIJ Int., 57 (2017), 1928. https://doi.org/10.2355/isijinternational. ISIJINT-2017-249

26) A. Kasai, M. Naito, Y. Matsui and Y. Yamagata: Tetsu-toHagané, 89 (2003), 1212 (in Japanese). https://doi.org/10.2355/ tetsutohagane1955.89.12 1212

27) A. Kasai and Y. Matsui: ISIJ Int., 44 (2004), 2073. https://doi. org/10.2355/isijinternational.44.2073

\section{Appendix Influence of Alkali Recirculation in BIS Test}

In plant blast furnaces, alkali recirculation within the furnace influences both carbon reactivity and reduction of sintered ores. We consider that the aforementioned influence is essential for performing process estimation by the BIS test. The following scheme of recirculation is well known. ${ }^{\mathrm{A} 1)} \mathrm{K}(\mathrm{g})$ and $\mathrm{KCN}(\mathrm{g})$ form from the heath slag at $1500^{\circ} \mathrm{C}$. These gases move upward with decrease in their temperature, resulting in partial condensation and oxidization to form $\mathrm{K}_{2} \mathrm{CO}_{3}(1)$ and $\mathrm{KCN}$ (1). With the descending of the charged materials, the temperatures of these liquids are increased and they vaporized again. Therefore, the influence of alkali in the BIS test was investigated. The condition of the BIS test was the same as that described in subsection

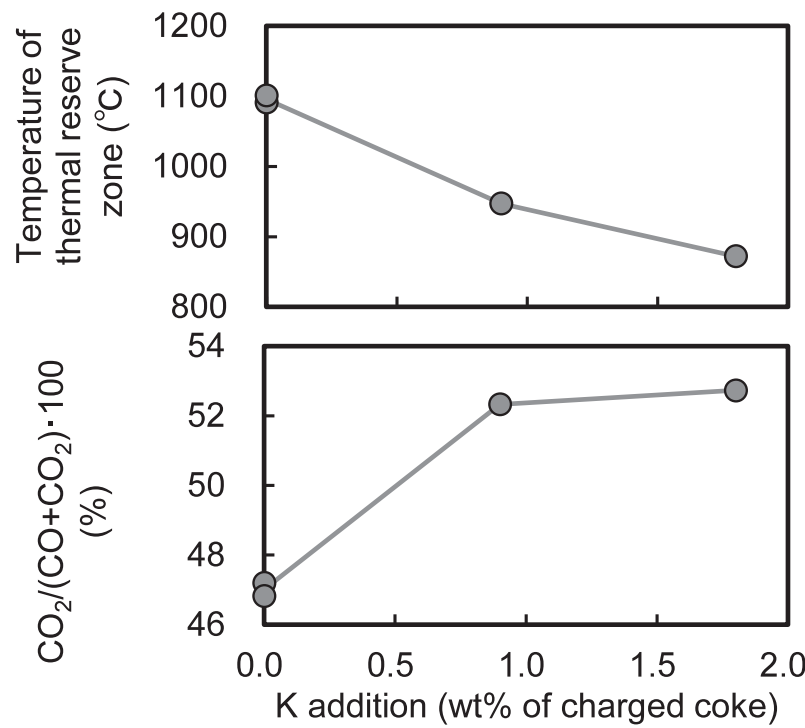

Fig. A1. Changes in the temperature of TRZ and gas utilization upon adding $\mathrm{K}$ in the BIS tests.

Table A1. $\mathrm{Na}_{2} \mathrm{O}+\mathrm{K}_{2} \mathrm{O}$ contents (wt $\%$ ) of the sum of sintered ores and coke below $1200^{\circ} \mathrm{C}$.

\begin{tabular}{lccccc}
\hline & \multicolumn{2}{c}{ BIS test } & \multicolumn{2}{c}{$\begin{array}{c}\text { Quenched blast } \\
\text { furnace }\end{array}$} & $\begin{array}{c}\text { Probe } \\
\text { sampling }\end{array}$ \\
\cline { 2 - 6 } & $\begin{array}{c}\mathrm{K} 0.9 \\
\mathrm{wt} \% \\
\text { addition }\end{array}$ & $\begin{array}{c}\mathrm{K} 1.8 \\
\mathrm{wt}^{\mathrm{add}}\end{array}$ & $\begin{array}{c}\text { Hirohata }^{\mathrm{A} 2)} \\
(1976)\end{array}$ & $\begin{array}{c}\text { Amagasaki } \\
(1980)\end{array}$ & $\begin{array}{c}\text { Oita } \\
(2007)\end{array}$ \\
\hline $\mathrm{Na}_{2} \mathrm{O}+\mathrm{K}_{2} \mathrm{O}$ & 0.18 & 0.27 & 0.33 & 0.21 & 0.27 \\
\hline
\end{tabular}

2.4. $\mathrm{KOH}$ (granular reagent grade, purity $85 \%$ ) was charged between an ore layer and a coke layer. The amount of charge was varied to attain $\mathrm{K}$ content of $0 \mathrm{wt} \%, 0.9 \mathrm{wt} \%$, and 1.8 $\mathrm{wt} \%$ in the charged coke.

Fig. A1 shows the result of the BIS test. The temperature of TRZ reduced and gas utilization increased upon adding alkali. The temperature of TRZ decreased to approximately $900^{\circ} \mathrm{C}$, which is a comparable value for plant measurement, between $0.9 \mathrm{wt} \%$ and $1.8 \mathrm{wt} \%$ of $\mathrm{K}$ addition. Table $\mathbf{A 1}$ shows the alkali content of the sum of sintered ores and coke until $1200^{\circ} \mathrm{C}$ in the BIS test, as well as the results of samples analysis after quenching blast furnaces ${ }^{\mathrm{A} 2, \mathrm{~A} 3)}$ and after sampling by a probe. The addition of $1.8 \mathrm{wt} \%$ of $\mathrm{K}$ in the BIS test resulted in a comparable alkali content of the changed materials, compared with those in the plant. Therefore, we decided to add $1.8 \mathrm{wt} \%$ of $\mathrm{K}$ in the BIS test, thereby demonstrating the recirculation of alkali in the plant.

\section{REFERENCES}

A1) J. M. Steiler, R. Nicolle, B. Metz, M. Wanin, C. Thirion and D. Flamion: Proc. 43rd Ironmaking Conf., AIME, Warrendale, (1984), 427.

A2) Y. Shimomura, K. Nishikawa, S. Arino, T. Katayama, Y. Hida and T. Isoyama: Trans. Iron Steel Inst. Jpn., 17 (1977), 381. https://doi. org/10.2355/isijinternational1966.17.381

A3) K. Narita, T. Sato, M. Maekawa, S. Fukihara, H. Kanayama and S. Sasahara: Tetsu-to-Hagané, 66 (1980), 1975 (in Japanese). https:// doi.org/10.2355/tetsutohagane1955.66.13_1975 